University of Nebraska - Lincoln

DigitalCommons@University of Nebraska - Lincoln

Publications from USDA-ARS / UNL Faculty

U.S. Department of Agriculture: Agricultural

Research Service, Lincoln, Nebraska

2014

\title{
Predicting phosphorus dynamics in complex terrains using a variable source area hydrology model
}

Amy S. Collick

Pasture Systems and Watershed Management Research Unit, USDA-ARS

Daniel R. Fuka

Department of Biological Systems Engineering, Virginia Tech

Peter J.A. Kleinman

Pasture Systems and Watershed Management Research Unit, USDA-ARS

Anthony R. Buda

Pasture Systems and Watershed Management Research Unit, USDA-ARS

Jennifer L. Weld

Department of Ecosystem Science and Management, Pennsylvania State University

See next page for additional authors

Follow this and additional works at: https://digitalcommons.unl.edu/usdaarsfacpub

Part of the Agriculture Commons, and the Environmental Sciences Commons

Collick, Amy S.; Fuka, Daniel R.; Kleinman, Peter J.A.; Buda, Anthony R.; Weld, Jennifer L.; White, Mike J.; Veith, Tamie L.; Bryant, Ray B.; Bolster, Carl H.; and Easton, Zachary M., "Predicting phosphorus dynamics in complex terrains using a variable source area hydrology model" (2014). Publications from USDA-ARS / UNL Faculty. 1518.

https://digitalcommons.unl.edu/usdaarsfacpub/1518

This Article is brought to you for free and open access by the U.S. Department of Agriculture: Agricultural Research Service, Lincoln, Nebraska at DigitalCommons@University of Nebraska - Lincoln. It has been accepted for inclusion in Publications from USDA-ARS / UNL Faculty by an authorized administrator of DigitalCommons@University of Nebraska - Lincoln. 


\section{Authors}

Amy S. Collick, Daniel R. Fuka, Peter J.A. Kleinman, Anthony R. Buda, Jennifer L. Weld, Mike J. White,

Tamie L. Veith, Ray B. Bryant, Carl H. Bolster, and Zachary M. Easton 


\title{
Predicting phosphorus dynamics in complex terrains using a variable source area hydrology model
}

\author{
Amy S. Collick, ${ }^{1}$ Daniel R. Fuka, ${ }^{2}$ Peter J. A. Kleinman, ${ }^{1}$ Anthony R. Buda, ${ }^{1}$ Jennifer L. Weld, ${ }^{3}$ \\ Mike J. White, ${ }^{4}$ Tamie L. Veith, ${ }^{1}$ Ray B. Bryant, ${ }^{1}$ Carl H. Bolster ${ }^{5}$ and Zachary M. Easton ${ }^{2 *}$ \\ ${ }^{1}$ Pasture Systems and Watershed Management Research Unit, USDA-ARS, University Park, PA 16802, USA \\ ${ }^{2}$ Department of Biological Systems Engineering, Virginia Tech, Blacksburg, VA, 24060 USA \\ ${ }^{3}$ Department of Ecosystem Science and Management, Pennsylvania State University, University Park, PA 16802, USA \\ ${ }^{4}$ Grassland Soil and Water Research Laboratory, USDA-ARS, Temple, TX 76502, USA \\ ${ }^{5}$ Animal Waste Management Research Unit, USDA-ARS, Bowling Green, KY 42104, USA
}

\begin{abstract}
:
Phosphorus (P) loss from agricultural watersheds has long been a critical water quality problem, the control of which has been the focus of considerable research and investment. Preventing P loss depends on accurately representing the hydrological and chemical processes governing P mobilization and transport. The Soil and Water Assessment Tool (SWAT) is a watershed model commonly used to predict run-off and non-point source pollution transport. SWAT simulates run-off employing either the curve number $(C N)$ or the Green and Ampt methods, both assume infiltration-excess run-off, although shallow soils underlain by a restricting layer commonly generate saturation-excess run-off from variable source areas (VSA). In this study, we compared traditional SWAT with a re-conceptualized version, SWAT-VSA, that represents VSA hydrology, in a complex agricultural watershed in east central Pennsylvania. The objectives of this research were to provide further evidence of SWAT-VSA's integrated and distributed predictive capabilities against measured surface run-off and stream P loads and to highlight the model's ability to drive sub-field management of P. Thus, we relied on a detailed field management database to parameterize the models. SWAT and SWAT-VSA predicted discharge similarly well (daily Nash-Sutcliffe efficiencies of 0.61 and 0.66 , respectively), but SWAT-VSA outperformed SWAT in predicting P export from the watershed. SWAT estimated lower P loss $\left(0.0-0.25 \mathrm{~kg} \mathrm{ha}^{-1}\right)$ from agricultural fields than SWAT-VSA $\left(0.0-1.0+\mathrm{kg} \mathrm{ha}^{-1}\right)$, which also identified critical source areas - those areas generating large run-off and P losses at the sub-field level. These results support the use of SWAT-VSA in predicting watershed-scale P losses and identifying critical source areas of P loss in landscapes with VSA hydrology. Copyright $\odot 2014$ John Wiley \& Sons, Ltd.
\end{abstract}

KEY WORDS curve number $(C N)$; watershed model; non-point source pollution; saturation excess; variable source area (VSA); water quality

Received 25 October 2013; Accepted 18 February 2014

\section{INTRODUCTION}

Correctly predicting phosphorus (P) loss from agricultural landscapes depends on accurately representing hydrological and chemical processes (Easton et al., 2009). Whereas much research has independently explored the source factors controlling P loss (e.g. solubility, amount, timing and application type) (Sharpley et al., 2002; Vadas et al., 2004; Kleinman et al., 2011) or the transport factors (e.g., run-off and interflow) (Needelman et al., 2004; Lyon et al., 2006; Easton et al., 2007), little research has addressed the interactive effects of these factors on P loss across complex terrains. This is primarily because of

*Correspondence to: Zachary M. Easton, Department of Biological Systems Engineering, Virginia Tech, Blacksburg, VA 24060, USA

E-mail: zeaston@vt.edu

USDA is an equal opportunity provider and employer. system complexity, multiple species of $\mathrm{P}$ in constant transformation, and differing hydrologic pathways that activate and deactivate with changing environmental conditions. Watershed planners and managers need tools that can capture the spatial and temporal complexity of agricultural landscapes in order to design effective longterm strategies for mitigating excess $\mathrm{P}$ loss to water bodies (Sharpley et al., 2011). As a result, water quality models are increasingly relied upon to represent P loss from agricultural watersheds under different land management or climate scenarios (Gitau and Veith, 2006; Duriancik et al., 2008; Easton et al., 2008; Van Liew et al., 2012; Bosch et al., 2013; Crossman et al., 2013; Niraula et al., 2013).

Most of these water quality models predict storm run-off using some form of the Natural Resources Conservation Service's Curve Number $(C N)$ equation (USDA-SCS, 1972) in a way that implicitly assumes run-off is generated 
only through infiltration-excess (or Hortonian, i.e. Horton, 1933) overland flow. In complex terrains where processes are spatially or temporally in unsteady state and in regions dominated by saturation-excess run-off processes, application of the $C N$ method has been extrapolated far beyond its initial design purpose (Gassman et al., 2007; Easton et al., 2008; White et al., 2009). In turn, run-off and P source areas may be misaligned, leading to ambiguous representations of $\mathrm{P}$ transfers and, perhaps more importantly, misguided management decisions (Qui et al., 2007; Ghebremichael et al., 2010). This may have contributed to the limited success in reducing non-point source nutrient pollution despite four decades of effort and millions of dollars invested (USEPA, 2002, 2006).

Alternatively, variable source area (VSA) hydrology is widely recognized as a primary driver of both run-off and $P$ loss in watersheds where shallow soils with nearsurface restricting layers or perched water tables generate zones of saturation-excess run-off that expand and contract over the period of an event (Beven, 2001; Srinivasan et al., 2002; Easton et al., 2008). Because of its simplicity and ubiquity in models, Steenhuis et al. (1995) and Lyon et al. (2004) suggested and Easton et al. (2008) later applied modifications to the $C N$ method to better represent saturation-excess run-off from VSAs. For example, Dahlke et al. (2009) found that coupling the 'VSA interpretation' of the $C N$ method with a simple water balance model predicted run-off generation consistent with field observations from Town Brook watershed in Upstate New York. Subsequent VSA modifications of the $C N$ method have been successfully integrated into existing water quality models (Generalized Watershed Loading Function, Schneiderman et al., 2007 and Soil and Water Assessment Tool (SWAT), Easton et al., 2008).

The SWAT is a watershed model of particular interest to conservation and nutrient management planning as it offers flexibility in the range of input data that can be used and employs process-based P cycling (Veith et al., 2008; Arnold et al., 2010; Nietsch et al., 2011). Easton et al. (2008) re-conceptualized SWAT to represent VSA hydrology (SWAT-VSA) and demonstrated improved predictions of run-off source areas and $\mathrm{P}$ loss in a glaciated watershed with shallow permeable soils above a relatively continuous restrictive layer on a steep to moderately sloped landscape. The promising results from that and other recent SWAT-VSA projects (Pradhanang et al., 2013; Woodbury et al., 2013) justify an expansion of its testing to more complex agricultural landscapes with more variably drained soils and a less consistent restrictive layer, all of which complicate the hydrologic and chemical processes.

This study comprehensively evaluates SWAT-VSA against a standard version of SWAT in WE38, a small $\left(7.3 \mathrm{~km}^{2}\right)$, geologically complex, upland, agricultural watershed in east central PA where VSA hydrology has been well documented (Gburek et al., 2002, 2006; Needelman et al., 2004; Veith et al., 2008; Buda et al., 2009a, 2013). Soils in the study watershed range from deep and well drained to shallow and poorly drained underlain by a fragipan. Long-term agricultural management records and a wealth of measured data made this watershed an ideal test site. The broad objectives of this research were to provide further evidence of SWAT-VSA's integrated and distributed predictive capabilities and to highlight the model's ability to drive sub-field management of P. The specific objectives of this study were to compare predicted overland run-off, interflow and in-stream P concentrations from both SWAT and SWAT-VSA with measured watershed data. Ultimately, our goals were to more accurately identify the critical P source areas, where high run-off potential and high potential $\mathrm{P}$ losses intersect in the watershed, using the most appropriate version of SWAT. Improved understanding and identification of critical $\mathrm{P}$ source areas will in turn provide policy makers and conservation personnel with more relevant information to drive agricultural management practices.

\section{MATERIALS AND METHODS}

We applied both SWAT and SWAT-VSA in the WE38 watershed and compared model predictions with measurements of stream flow and dissolved $\mathrm{P}$ in the stream and distributed measures of soil moisture and run-off frequency obtained from eight hillslope soil trenches located in areas with and without fragipan restricting layers (Figure 1). The initializations of both versions of SWAT reflect an intense focus on two sub-watersheds of WE38, FD36 and Mattern, which have undergone extensive hydrological investigation. Characterizations of these two sub-watersheds from previous studies (Gburek et al., 2002, 2006; Needelman et al., 2004; Veith et al., 2008; Buda et al., 2009a, 2013) were used to parameterize the model and corroborate model predictions. Multi-year field management schedules were built into the models for each individual agricultural field within the two sub-watersheds. Note that we did not calibrate either model to improve $\mathrm{P}$ predictions but rather relied on a detailed field management database and expert scientific knowledge of the watersheds to parameterize the models. This enabled an unbiased determination of the effect of incorporating VSA into SWAT on P predictions.

\section{Watershed description}

WE38 is a first-order upland agricultural watershed in the Ridge and Valley physiographic region of south central Pennsylvania and has undergone intensive study and experimentation by the USDA-ARS since 1968 


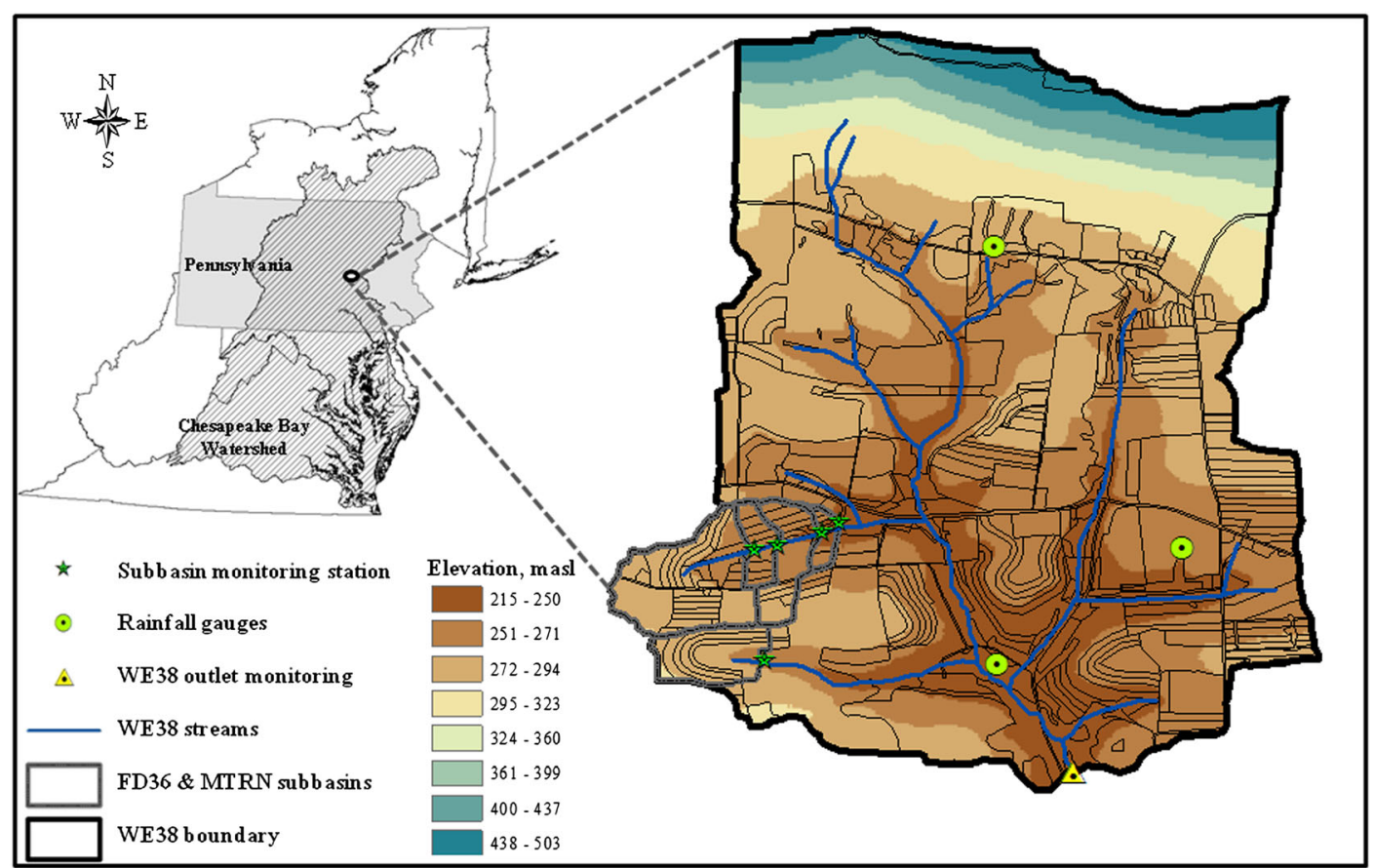

Figure 1. Location of WE38, digital elevation model, agricultural fields and monitoring stations and gauges in south central Pennsylvania, USA

(Figure 1). As a result, extensive hydrological, weather, soil, water quality and farm management data for extended durations are available (Bryant et al., 2011). Mean elevation in WE38 is $286.4 \mathrm{~m}$ (range 214.6 and $503.3 \mathrm{~m}$ ), and the climate is temperate and humid with average annual rainfall of $1065 \mathrm{~mm}$ year $^{-1}$ and streamflow of $450 \mathrm{~mm}_{\text {year }}{ }^{-1}$. The most prevalent watershed soils are Calvin (loamy-skeletal, mixed, active, mesic Typic Dystrudepts), Klinesville (loamy-skeletal, mixed, active, mesic Lithic Dystrudepts), Berks (loamy-skeletal, mixed, active, mesic Typic Dystrudepts), Meckesville (fine-loamy, mixed, active, mesic Typic Fragiudults), Harleton (loamyskeletal, mixed, active, mesic Typic Hapludults), Leck Kill (fine-loamy, mixed, semiactive, mesic Typic Hapludults) and Albrights (fine-loamy, mixed, semiactive, mesic Aquic Fragiudalfs). Well-drained, medium-textured Dystrudepts and Hapludults cover the upper ridges and steep sides of the valley. Typic and Aquic Fragiudults and Fragiudalfs formed in multiple layers of medium to poorly drained colluvial deposits occupy the lower footslopes and valley floors directly adjacent to the valley bottoms (Bryant et al., 2011).

Discharge has been measured at 5-min intervals at the main outlet of WE38 since 1968 (available on a daily time step on STEWARDS database) (Buda et al., 2011b) and since the late 1990s or 2000s at the outlets of Mattern (2001 to present) and FD36 (1996 to present) and three subbasin flumes within FD36 (Figure 1). Three precipitation gauges located throughout WE38 (Figure 1) measured precipitation at 5-min intervals since 1968 at two sites and since 1979 at the third site (Buda et al., 2011a). Since 1984, at the main outlet of WE38, orthophosphate concentrations have been measured according to EPA standards from single-grab samples collected three times per week irrespective of hydrologic events (Church et al., 2011).

For spatially distributed run-off comparisons, we used run-off data from eight hillslope trenches (four each in Mattern and FD36 watersheds). The location of each trench and a description of its soils are given in Lindeburg (2011). Hillslope trenches were intended to provide simultaneous measurements of overland flow and subsurface flow draining three distinct soil horizons (Ap and two different B horizons). Briefly, a 25-cm-tall earthen berm was used to direct overland flow to a slotted PVC pipe $(3 \mathrm{~cm}$ diam $\times 300 \mathrm{~cm}$ long), which was situated just upslope of the berm. The pipe drained overland flow by gravity to an HS flume equipped with a pressure transducer, which measured stage height at 5-min intervals that could then be converted to discharge using a standard flume equation. Subsurface flow was collected in rain gutters $(15 \mathrm{~cm}$ wide $\times 15 \mathrm{~cm}$ deep $\times 300 \mathrm{~cm}$ long $)$ that were aligned parallel with the base of each of the three soil horizons. Flows were directed to tipping buckets ( $\sim 700 \mathrm{~mL}$ per tip) that provided discharge readings every $5 \mathrm{~min}$.

Land use in WE38 is dominated by agriculture (44.5\%) and forest $(38.8 \%)$. The majority of the forest lies in the northern uplands of the watershed with woodlots intermixed on farms in between agricultural fields concentrated near the stream network. Agriculture is 
primarily a mixed cropping system in which soybean (Glycine max), small grains [wheat (Triticum aestivum), barley (Hordeum vulgare L.) and rye (Secale cereale)], corn (Zea mays L.) or hay [alfalfa (Medicago sativa L.), clover, timothy (Phleum pratense) and other grasses] are cultivated either continuously, double cropped or mixed (small grain as nurse crops). The remaining land use in the watershed consists of continuous pasture (3.5\%), Christmas tree plantations (2.2\%), fallow and grasslands ( $0.9 \%)$, fields converted to Conservation Reserve Enhancement Program $(3.1 \%)$ and developed areas (paved roadways, grass lanes, residences or farm structures) (6.2\%). Less than $1 \%$ of the WE38 watershed is classified as permanent open water.

Geomorphic features in the watershed are typical of the Appalachian Valley and Ridge Province and result in spatially and temporally discrete run-off generation mechanisms. As documented for both the Mattern (Buda et al., 2009a, 2013) and FD36 (Gburek et al., 2002, 2006; Needelman et al., 2004; and Veith et al., 2008) subwatersheds, saturation-excess run-off generation from soils with fragipans at lower landscape positions accounts for the majority of surface run-off: greater than $80 \%$ according to Buda et al. (2009a). Surface run-off from upslope soils lacking fragipans is comparatively infrequent, generally by infiltration-excess mechanism under high-intensity storms, and of comparatively low volume (Buda et al., 2009a).

\section{SWAT description}

Model overview. The SWAT is a watershed-scale, physically based model incorporating weather, soil, land cover and land management data to simulate surface and subsurface hydrology and various chemical and sediment fluxes. SWAT requires spatial data for soils, land use/ management and elevation. Although these data are spatially explicit GIS files, SWAT lumps unique combinations into hydrologic response units (HRUs) during the initialization process. Although this lumping process reduces computational complexity, it effectively ignores the underlying spatial distribution of the input data within a subbasin. Traditionally, HRUs are defined by the coincidence of soil type, land use and, if desired, slope. Thus, all HRUs containing the same soil type, land use and slope class have identical properties irrespective of where they are located within a subbasin. Simulations require meteorological input data including precipitation, temperature, relative humidity, wind speed and solar radiation.

Input data. Spatial data: Elevation data, spatial and tabular attribute land use, and spatial and tabular soils are required landscape data for model initialization. A digital elevation model (DEM) with a resolution of $1 / 3$ arcsecond (roughly $10 \mathrm{~m}$ ) was obtained for the watershed area from the National Elevation Dataset (NED) developed by the US Geological Survey (USGS) (http://ned. usgs.gov). The DEM for WE38 was developed by masking the NED dataset with the WE38 watershed boundary described by Bryant et al. (2011). Each of the flume basin boundaries in Figure 1 in Mattern and FD36 was burned manually into the masked DEM.

For standard SWAT, the spatial and tabular soil data were downloaded from the Soil Survey Geographic Database (SSURGO) website (USDA-NRCS, 2008). Soil attributes were gathered from the SSURGO database established for SWAT (http://swat.tamu.edu/media/ 63316/SWAT_US_SSURGO_Soils.zip), and the soil spatial layer and its lookup table were formatted for use in SWAT. SWAT-VSA uses the same spatial and tabular land use as does SWAT but replaces the commonly used STATSGO or SSURGO soil layer with a spatial combination of the FAO-UNESCO Digital Soil Map of the World (FAO, 2007) and topographically-derived wetness classes. The derivation of the wetness class layer follows.

Topographic indices $(T I)$ represent the propensity of a landscape unit to soil saturation and subsequent run-off generation by combining two important controls on these processes, upslope contributing area $(\alpha)$ that drains through any given point and local slope gradient $(\tan \beta)$ (Beven and Kirkby, 1979; Easton et al., 2008):

$$
T I=\ln \left(\frac{\alpha}{\tan \beta}\right)
$$

To represent VSA hydrology in SWAT, we used the DEM and ArcMap hydrology tools to calculate a TI layer at the same grid resolution of the DEM. The $T I$ layer was then resampled to create a wetness class layer by dividing the $T I$ values into ten equal area wetness classes, which ranged from a wetness class one (10\% of the watershed with the lowest likelihood of run-off) to a wetness class ten $(10 \%$ of the watershed with the highest likelihood of run-off). Finally, we used TopoSWAT (Fuka et al., 2013), an automated ArcMap toolbox, to overlay the FAO-UNESCO Digital Soil Map of the World (FAO, 2007) layer with the wetness class layer, which creates the HRU layer and associated lookup tables.

While SWAT can take advantage of more detailed soil layers, we used measured soil pedon data (soil depth by layer and texture analysis) from the eight hillslope trenches (Lindeburg, 2011) within the watershed to parameterize the SWAT-VSA soil database. Soil data from each of the trenches were cross correlated with the $T I$ class in which each trench was located, and the linear relationship between the measured soil parameters and the TI classes was established (Figure 2a and b). Soil depth (Figure 2a) and texture (percent sand and clay) (Figure 2b) were applied directly to the soils associated with each $T I$ 

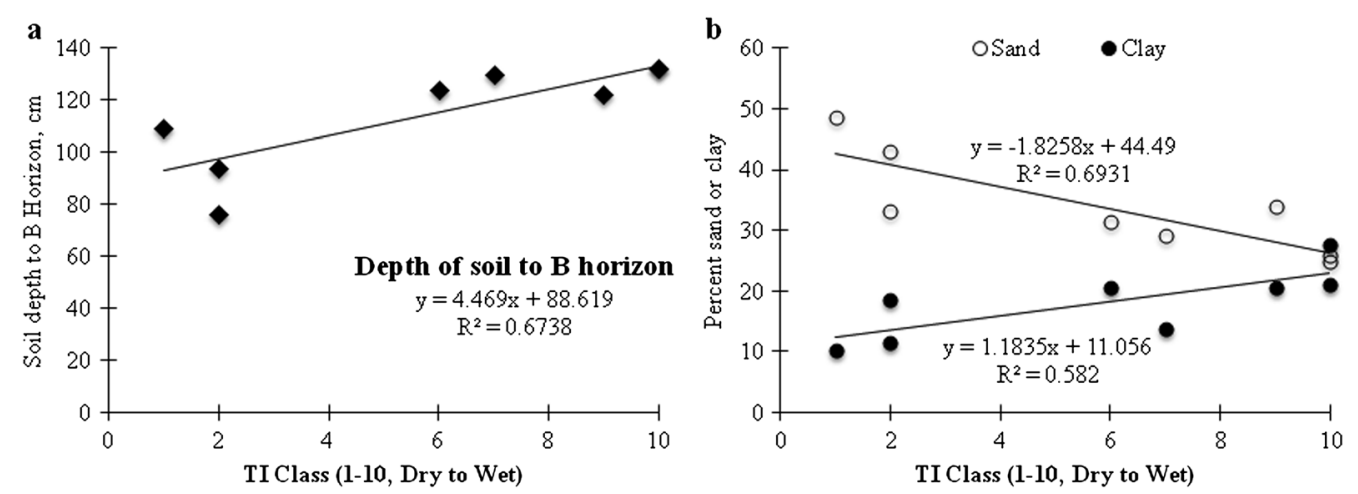

Figure 2. Relationship of soil depth (a) and clay and sand content (b) in FD36 and Mattern watersheds to topographic indices (TI) classes for parameterization of WE38 soils in Soil and Water Assessment Tool-variable source area

class in SWAT. Those parameters not measured in the eight soil pedons, such as field capacity and wilting point soil moisture capacity and available water content, were calculated using the soil water characteristics calculator from Saxton and Rawls (2006) and applied to the $T I$ based soils in the model.

Required meteorological data: Daily precipitation data were collected from three weather stations located in WE38 (Figure 1). Daily measurements of minimum and maximum temperature, relative humidity, photosynthetically active radiation (PAR) $\left(\mu \mathrm{mol} \mathrm{s} \mathrm{m}^{-1}\right)$ and wind speed were obtained from a meteorological monitoring station situated in the southeastern area of WE38. The daily PAR were converted to $\mathrm{MJ} \mathrm{m}^{-2}$ and used to estimate daily potential evapotranspiration using the Penman-Monteith method.

Management operations: The study watershed, although part of the long-term USDA-ARS Mahantango Experimental Watershed, is comprised of several privately owned and operated farms. To facilitate experimental research, these farmers have generously contributed to a 12-year collection effort (1999-2010) of detailed field-byfield agricultural management schedules throughout the watershed. The information has been consistently collected for each farm in WE38 by a single individual, which minimizes bias. Data gathering techniques include annual farmer interviews, informal updates throughout the year, and regular field observations. In order to incorporate this management information into SWAT and SWAT-VSA, georeferenced field boundaries were obtained annually by GPS, reconciled against publically available aerial satellite photos, and combined to represent the changing shape and size of the fields over the 12 years of the study. Non-agricultural land use polygons (woodlots, forest, transportation routes, residences and farm structures) were delineated and merged with the union of the farm fields into a multi-year land use layer that spans the watershed.
To maximize the benefit of the detailed farm and field management data, it was necessary that the land use layer captured all spatial and temporal changes in the management boundaries. Thus, the SWAT land use layer was delineated to maintain the most detailed combination of farm and field boundary intersections across the study period. Each farm field was composed of a combination of HRUs and general field management parameters together with chronological field management operations (planting, tillage, fertilizer application and harvesting practices for each year, Table I). Management operations were assigned to the HRUs within each individual field on a rotational basis or on an annual basis depending on the operation. Field results were summarized from the area-weighted output of all the HRUs within the field boundary.

Mineral $\mathrm{P}$ and nitrogen were supplied by both chemical and manure fertilizers for a broad range of crops across farms in the watershed. Only three farms regularly applied animal manure (beef, dairy or poultry), and limited information was available regarding manure applications from grazing. Manure supplies the majority of mineral $\mathrm{P}$ with an annual average application rate of $7 \mathrm{~kg} \mathrm{ha}^{-1}$. In contrast, mineral $\mathrm{N}$ was supplied primarily by chemical fertilizers, which were applied most intensively in the early spring months at rates averaging $55 \mathrm{~kg} \mathrm{ha}^{-1}$.

Lateral flow compensations: Neither SWAT nor SWATVSA currently route run-off or lateral flows from HRU to HRU, across the landscape. In areas exhibiting VSA-type hydrology, water contribution from upslope areas to downslope areas via lateral flow is a critical control on both run-off generation and nutrient cycling (Weyman, 1973), primarily because of increased soil moisture. In SWAT and SWAT-VSA, lateral flow is calculated for each HRU but is added directly to the subbasin reach. These lateral flows can be lagged by specifying an exponential lag time, which functionally compensates for 


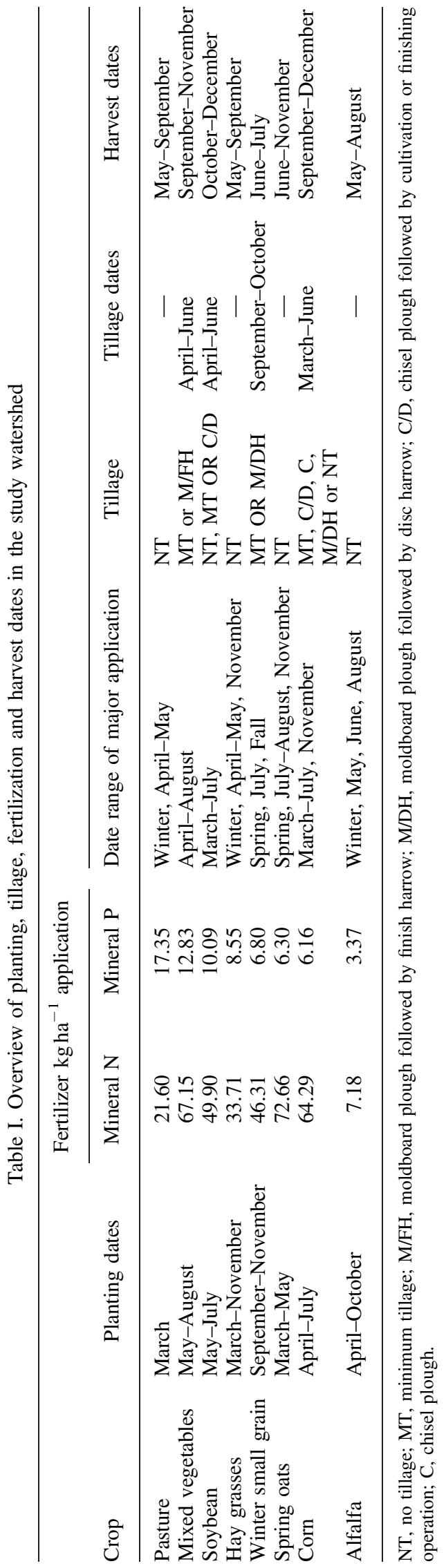

the time differential between lateral flow being added to the reach once generated and the physical routing between HRUs (Nietsch et al., 2009, Section 2:3.5.1 Lateral Flow Lag). This functional lack of HRU to HRU routing creates a water mass balance error in SWATVSA's vadose zone, with soils in a higher topographic wetness class (e.g. in areas receiving lateral flows from upslope) being too dry. Figure 3 illustrates the influence of lateral flow on soil moisture in the FD36 subwatershed, notice that higher wetness classes have greater water content than lower wetness classes.

In an effort to capture the influence of lateral flow, at the HRU scale, we employed functionality already built into SWAT, the HRU autoirrigation routine, which adds water from a subbasin reach to landscape HRUs. Specifically, we used the reach as an aquifer storage pool that can increase and decrease volume concomitant with in-reach flow rates. The autoirrigation routine withdraws water from the reach to maintain the soil water content at field capacity of a given HRU as long as the in-stream flow rate was above a minimum threshold. We assume that streamflow flow rate was a function of the saturation status of the watershed and set the autoirrigation routine to transfer water from the reach to a $T I$ class at a given flow rate/saturation status. The flow rate in the reach was scaled linearly from $0 \%$ at no flow to $100 \%$ at peak flow, to represent the natural relationship of streamflow to watershed soil moisture content (Hewlett and Hibbert, 1963). It should be noted that this adjustment does not change the overall subbasin water balance, it simply adjusts where the water is located in the subbasin.

To determine the in-reach minimum flow rates for autoirrigation transfers to begin, we first determined the baseflow rate using a baseflow separation technique (Lyne and Hollick, 1979; Nathan and McMahon, 1990; Archibald, 2013) and assumed that when the baseflow rate was at the maximum for a subbasin, the watershed moisture storage was also at its maximum (e.g. saturated). The flow rate in the reach that required to initiate transfer

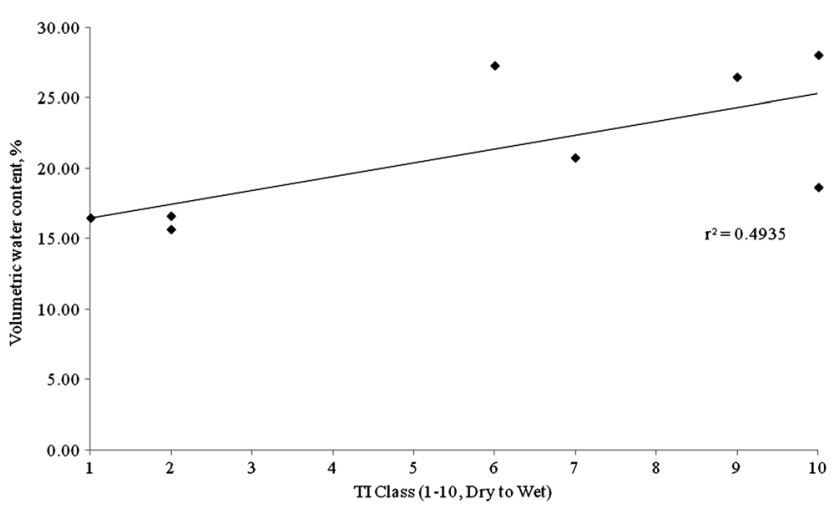

Figure 3. Relationship between average volumetric water content measured at eight hillslope trenches and topographic index (TI) classes 
of water from the reach into a $T I$ class was then determined from the percentage of the basin that was effectively saturated:

$$
Q_{b}=k_{1} \exp \left(k_{2}(1-\Theta)\right)
$$

where $Q_{b}$ is the baseflow rate, $k_{1}$ is a fitting coefficient, $k_{i}$ is the fractional saturated area of the watershed (determined from the wetness index, Easton et al., 2008) and $\Theta$ is the soil water content. The $Q_{b} / k_{1}$ factor is scaled from $1 \%$ to $100 \%$, assuming the maximum baseflow rate obtained from a baseflow separation of the historical record can be substituted for the theoretical maximum baseflow rate $\left(Q_{b \max }\right)$. Assuming the basin is $100 \%$ saturated when $\Theta=1$, we solve for the threshold flow rate at which additions begin for each $T I$ class. The threshold flow rate calculated for each TI class becomes the autoirrigation parameter FLOWMIN in the SWAT management files (Figure 4). Higher TI classes (more likely to saturate, $T I 9$ and $T I 10$ ) have a lower threshold indicating that autoirrigation additions will occur more frequently than lower $T I$ classes ( $T I 1$ and $T I 2$ ) where autoirrigation additions occur only at very high flow rates, indicating that the watershed, as a whole, was more saturated (Figure 4). This method provides a more parsimonious means of determining the soil moisture status of a given $T I$ class by directly linking it to the instream flow rates and the saturation status of the watershed. This in turn reduces calibration needs of the model and we believe provides more meaningful results.

Model calibration. Both models were run from 1987 to 2010 and were calibrated for flow from 2001 to 2008 but were not calibrated for P. In order to reduce calibration complexity and maintain as parsimonious model as possible, we first determined the lumped, basin-wide parameters, most specifically the basin average $C N$ and storage. These were calibrated from the time series of measured WE38 outflow using the Differential Evolution Optimization (DEoptim) package (Ardia and Mullen, 2009) in R. (R Core Team, 2013). In this step, we treated the watershed initialization as a linear model type response function for basin-wide parameters estimation (e.g. determining the $C N$ and storage on the basis of stream response to the weather input). Once these basinwide parameters were determined, we then distributed them across the full model using the method developed in Easton et al. (2008). In order to impose the distribution of saturated and run-off-generating areas across the landscape, we adapted the method of Easton et al. (2008): briefly, the calibrated but lumped watershed $C N$ was used to calculate the $C N_{I I}$ values (average antecedent moisture condition) for SWAT-VSA's wetness index classes and basin-wide storages. These storages were then used to distribute the local soil moisture storage deficits across the basin according to the $T I$.

The parameters determined earlier were applied to the traditional SWAT and modified SWAT-VSA models and HRU parameters in Table II calibrated to maximize the Nash-Sutcliffe efficiency (NSE, Nash and Sutcliffe, 1970), which measures both the variance of the predictions and the overall $1: 1$ fit between observed and simulated stream discharge on a daily time step using the DEoptim package in R (Ihaka and Gentleman, 1996; $\mathrm{R}$ Core Team, 2013). Note however that the $C N$ and storage parameter distribution calculated by the Easton et al. (2008) method were not calibrated again. In DEoptim, the number of guesses for the optimal value of the parameter vector (NP) was set to eight, and the number of iteration cycles over NP guesses (itermax) was set to 200. Each optimization converged at iteration 100 , so this value did not seem to influence the optimization. Twelve model parameters were calibrated during optimization (Table II).

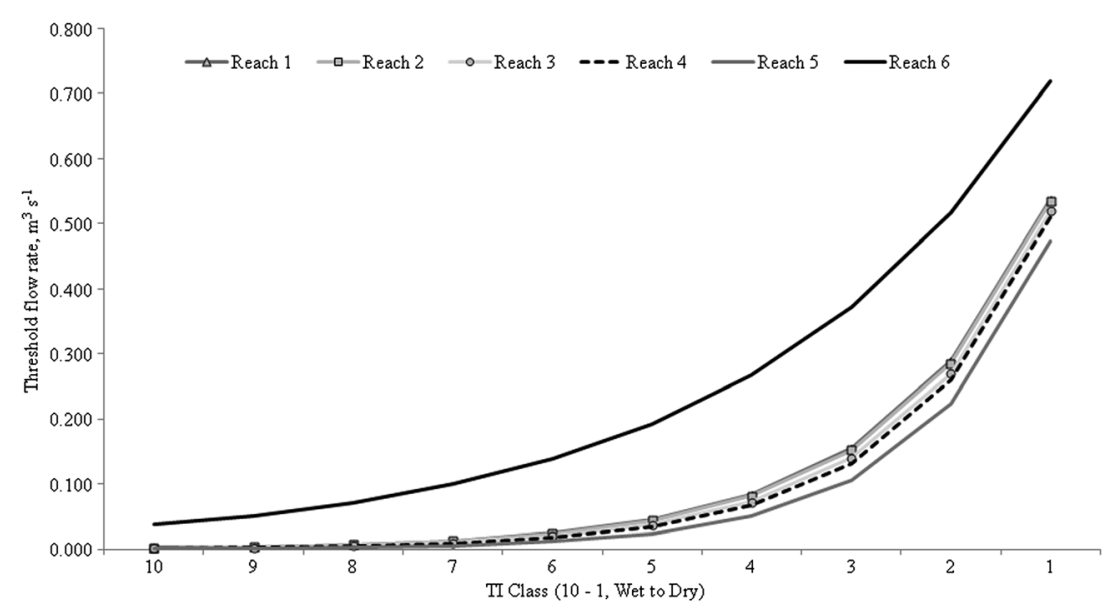

Figure 4. Minimum threshold flow rates for each topographic index (TI) class from the six subbasin watershed stream reaches 
Table II. Calibrated parameters used for Differential Evolution Optimization, within an initial range published in the literature

\begin{tabular}{llr}
\hline Variable & \multicolumn{1}{c}{ Definition } & Range \\
\hline GW_DELAY & Groundwater delay (days) & $1-180$ days \\
ALPHA_BF & Baseflow alpha factor (days) & $1-180$ days \\
SURLAG & Surface run-off lag time (days) & $1-180$ days \\
GWQMN & Threshold depth of water in the shallow aquifer (m) & $1-200 \mathrm{~mm}$ \\
ESCO (basin-wide) & Soil evaporation compensation factor & $0.2-0.99$ \\
EPCO (basin-wide) & Plant uptake compensation factor & $0.2-0.99$ \\
CN & Average SCS CN II value & $40-85$ \\
RCHRG_DP & Deep aquifer percolation fraction & $0-1.0$ \\
REVAPMN & Depth of water in the aquifer for revap (mm) & $0-500 \mathrm{~mm}$ \\
GW_REVAP & Groundwater 'revap' coefficient & $0-0.2$ \\
ESCO (HRU) & Soil evaporation compensation factor & $0.2-0.99$ \\
EPCO (HRU) & Plant uptake compensation factor & $0.2-0.99$ \\
\hline
\end{tabular}

Again, note that the models were only calibrated for flow and not for $\mathrm{P}$ because the goal of this project was to assess the ability of either model to suitably represent $P$ source areas and transfers, particularly in areas with little measured data.

Corroboration. In this paper, we avoid the oftenmisused term validation and instead consider model corroboration to be the best achievable measure of model performance. Reckhow and Chapra (1983) argue, 'The evaluation of water quality models may proceed according to inductive logic, the hypothetico-deductive approach or perhaps according to a falsification criterion. The result of successful (model) testing is at best corroboration, which is not truth but rather measured consistency with empirical evidence'. Beven and Young (2013) offer more recent arguments as to why modellers should avoid the term validation and suggest corroboration as a more suitable term. Thus, we corroborated SWAT-VSA and SWAT predictions by comparing both lumped (run-off and P load at the watershed outlet) and distributed (run-off event frequency, run-off volume and $\mathrm{P}$ loss) predictions to direct hydrologic and water quality measurements. For each constituent, model performance was evaluated using four methods: (1) qualitatively using time series plots; (2) quantitatively using the NSE; (3) percent bias; and if applicable, (4) the coefficient of determination $\left(r^{2}\right)$.

As an additional comparison, we also evaluated both versions of SWAT in this study against previous WE38 and FD36 modelling efforts performed by Van Liew et al. (2007), in which their model was calibrated between 1997 and 2000 and corroborated between 1989 and 1993 in both WE38 and FD36. The Van Liew et al. (2007) time periods occurred during our model run-up years and overlapped with the management operations of our current model, which allows us to confirm that our calibrations performed as well as those done previously in these watersheds.

\section{RESULTS AND DISCUSSION}

\section{Watershed discharge}

Both SWAT and SWAT-VSA performed similarly and compared well with measured discharge at the outlet of $7.3 \mathrm{~km}^{2}$ WE38 watershed (0.61 and 0.66 , NSE, respectively). Both model hydrographs corresponded well with measured discharge from WE38 (Figure 5), and predicted flow did not differ significantly (Figure 5 regression inset) between either versions of SWAT. Notably, extreme events (e.g. flows $>1 \mathrm{~m}^{3} \mathrm{~s}^{-1}$ ) were underestimated by SWAT and SWAT-VSA (e.g. 18 September 2004; 28 June 2006, 5 March 2008 and 1 December 2010) (Figure 5 residuals). The greatest underestimation (more than 59\% for both models) occurred on 5 March 2008, and other examples of underestimation of nearly $49 \%$ (SWAT-VSA) and 63\% (SWAT) occurred during heavy storms on 28 June 2006 when flooding occurred across northeastern USA and on 18 September 2004 when Hurricane Ivan was tracking northward through the midAtlantic region. Note that the gauges measuring discharge were inundated during these events, and thus, the 'measured' values were extrapolated, possibly far beyond the stagedischarge calibration curve. The greatest overestimation by SWAT and SWAT-VSA occurred on a series of days: 17-20 September 2004 and 3-5 January 2005.

The periods between 1989 and 1993 and between 1997 and 2000 coincided with WE38 corroboration and calibration, respectively, in Van Liew et al. (2007) and served as a benchmark of comparison with previous modelling efforts in the watershed (Table III). Both SWAT and SWAT-VSA performed similarly and produced slightly better model results between 1997 and 2000 than the results reported in Van Liew et al. (2007) (NSEs in the upper 0.6 ranges vs the upper 0.4 range). However, when comparing the current model's output with the previous study's output between 1989 and 1993, the Van Liew et al. (2007) studies performed slightly 


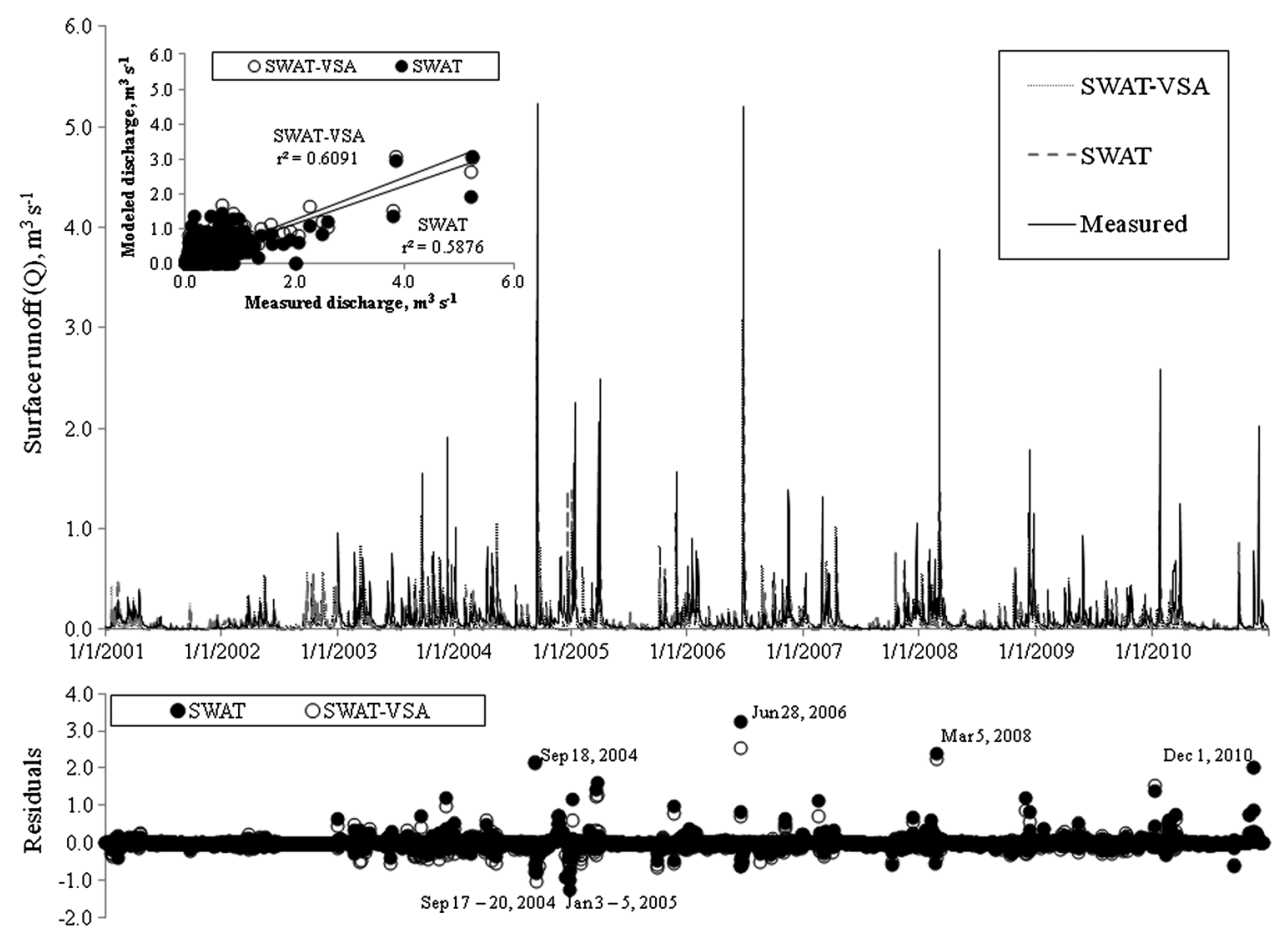

Figure 5. Hydrograph comparing Soil and Water Assessment Tool (SWAT), SWAT-variable source area (SWAT-VSA) and measured discharge at the outlet of WE38, Mahantango Creek, from 2001 to 2010. Plot of the models' linear regression is available in the inset. Residuals are also plotted along the same timeline as the hydrograph, and specific dates of overestimation and underestimation are indicated

Table III. Comparison statistics for Soil and Water Assessment Tool (SWAT) and SWAT-variable source areas flow during the different calibration and corroboration periods of the current runs and those from Van Liew et al. (2007), in bold

\begin{tabular}{|c|c|c|c|c|}
\hline Study & Run type & Time series & $\%$ Bias & Daily NSE \\
\hline \multicolumn{5}{|l|}{ WE38 } \\
\hline SWAT & Calibration & 2001-2008 & 7.7 & 0.61 \\
\hline SWAT-VSA & Calibration & 2001-2008 & 13.6 & 0.66 \\
\hline Van Liew et al. (2007) & Calibration & 1997-2000 & 15.8 & 0.46 \\
\hline SWAT & Corroboration & 1997-2000 & 8.2 & 0.33 \\
\hline SWAT-VSA & Corroboration & 1997-2000 & 16.3 & 0.41 \\
\hline Van Liew et al. (2007) & Corroboration & 1989-1993 & 33.1 & 0.43 \\
\hline SWAT & Corroboration & 1989-1993 & 32.7 & 0.34 \\
\hline SWAT-VSA & Corroboration & 1989-1993 & 37.7 & 0.29 \\
\hline SWAT & Corroboration & 2009-2010 & 32.3 & 0.40 \\
\hline SWAT-VSA & Corroboration & 2009-2010 & 38.9 & 0.32 \\
\hline \multicolumn{5}{|l|}{ FD36 } \\
\hline Van Liew et al. (2007) & Calibration & 1997-2000 & 23.5 & 0.69 \\
\hline SWAT & Corroboration & 1997-2000 & 17.5 & 0.56 \\
\hline SWAT-VSA & Corroboration & 1997-2000 & 22.5 & 0.64 \\
\hline SWAT & Calibration & 2001-2008 & 4.8 & 0.85 \\
\hline SWAT-VSA & Calibration & 2001-2008 & 5.5 & 0.87 \\
\hline
\end{tabular}

NSE, Nash-Sutcliffe efficiency; SWAT, Soil and Water Assessment Tool; VSA, variable source area.

better. At the subbasin level, model corroborations in FD36 from 1997 to 2000 were rather good and comparable with that of Van Liew et al. (2007); note that we only calibrated the model at the significantly larger WE38 level basin and extracted results for the
FD36 subbasin. The greater NSE (0.64) of SWAT-VSA suggests that this model better simulates the run-off processes previously documented in the FD36 subbasin (Gburek et al., 2002, 2006; Needelman et al., 2004; Veith et al., 2008). 


\section{Watershed phosphorus export}

Predicted soluble $\mathrm{P}$ loss $\left(\mathrm{kg} \mathrm{ha}^{-1}\right)$ from SWAT and SWAT-VSA compared adequately with measured $\mathrm{P}$ (Figure 6), with NSE and coefficient of determination $\left(r^{2}\right)$ values of 0.12 and 0.17 and 0.16 and 0.20 , respectively. Note however that no $\mathrm{P}$ parameters were calibrated in either model as the purpose of the exercise was to evaluate SWAT's ability to predict P loss in areas with little calibration data. In addition, measured $\mathrm{P}$ data were available for comparison with model output only $25 \%$ of the days from 2001 to 2008 , and the single-grab sample measurements of $\mathrm{P}$ may not necessarily represent an average concentration for the entire day. Both versions of SWAT underestimated P loss by greater than $89 \%$ during the heavy flooding event from 25 June to 28 June 2006 (230 mm of cumulative rain) when P loss was recorded above $0.050 \mathrm{~kg} \mathrm{ha}^{-1}$ (Figure 7). In addition, on 2 March 2007, both models again underestimated P loss by more than $98 \%$ (Figure 7). Snowmelt plus rainfall generated the high $\mathrm{P}$ loss. The elevated $\mathrm{P}$ loss in the spring could be explained by high levels of fertilizers being applied in late winter and early spring to precede the planting of the fields in May and June. Overestimation by the model coincides with the large rainfall events in the fall (September and October), marked by fertilizer applications for wintering crop. Periods of underestimation by SWAT and SWAT-VSA coincide with high discharge events: during snow melt events in late winter, heavy rains in early spring, and during heavy storm events in the fall during planting (winter crops) fertilizer application. These results during critical farm management activity periods warrant further investigation but as a whole indicate inadequate representation of surface applied P loss by current SWAT P routines, and thus, there is a strong interest in eventually revising SWAT with more management-driven $\mathrm{P}$ routines (e.g., Vadas et al., 2009).

The timing and quantity of $\mathrm{P}$ loss as predicted by SWAT-VSA correlated better with observed P export than SWAT (Figures 6 and 7). The log-log plots in Figure 6 indicate that SWAT-VSA was able to better

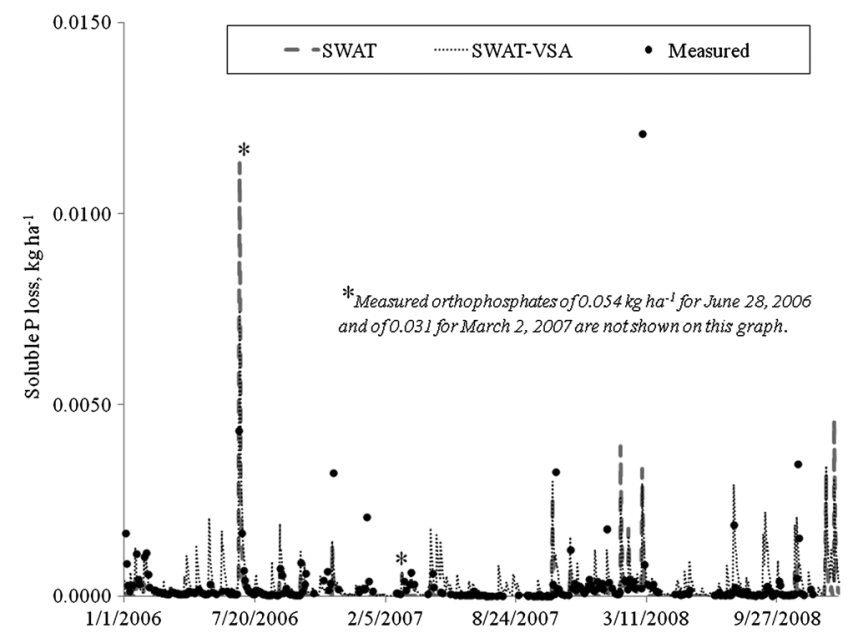

Figure 7. Chemograph from 2006 to 2008 comparing measured orthophosphates with both Soil and Water Assessment Tool (SWAT) and SWAT-variable source area (SWAT-VSA)

capture the range and magnitude of $\mathrm{P}$ export from the watershed, whereas SWAT predicted a smaller range of $\mathrm{P}$ export (e.g. more constant concentration). Figure 7 further indicated that SWAT-VSA was better able to predict $\mathrm{P}$ export; the cumulative $\mathrm{P}$ export was well represented until the large flooding event in 2006, where a large flux of $\mathrm{P}$ $\left(0.054 \mathrm{~kg} \mathrm{ha}^{-1}\right.$, Figure 8) was measured. Despite the discontinuity introduced by this event, SWAT-VSA was still able to predict the temporal dynamics of $\mathrm{P}$ export. This indicates that SWAT-VSA was at least able to maintain an acceptable P mass balance, whereas SWAT cannot adequately predict the total mass of $\mathrm{P}$ leaving the watershed.

\section{Comparison with subbasin and distributed data}

In an effort to corroborate the distributed predictions made by SWAT and SWAT-VSA, we compared HRU, wetness class and field level outputs with measurements made in the watershed. Specifically, we compared model data against run-off frequency, run-off flow volume and estimates of $\mathrm{P}$ loss. The data obtained from the eight hillslope trenches described by Lindeburg (2011) provided

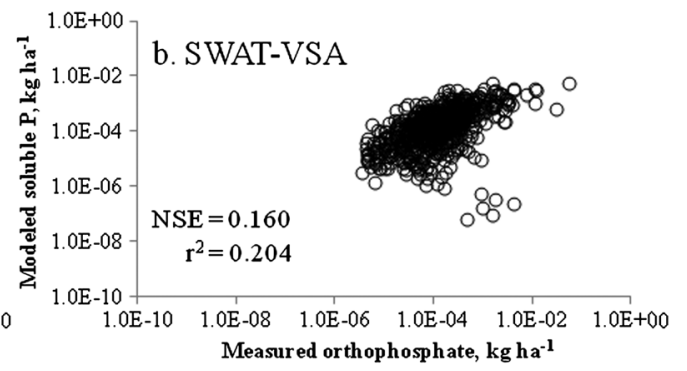

Figure 6. Predicted soluble P loss compared with measured orthophosphate for Soil and Water Assessment Tool (SWAT) (a) and SWAT-variable source area (SWAT-VSA) (b) from 2001 to 2008 plotted on log-log axes. Nash-Sutcliffe efficiencies (NSE) and coefficient of determination $\left(r^{2}\right)$ of the comparison are included 


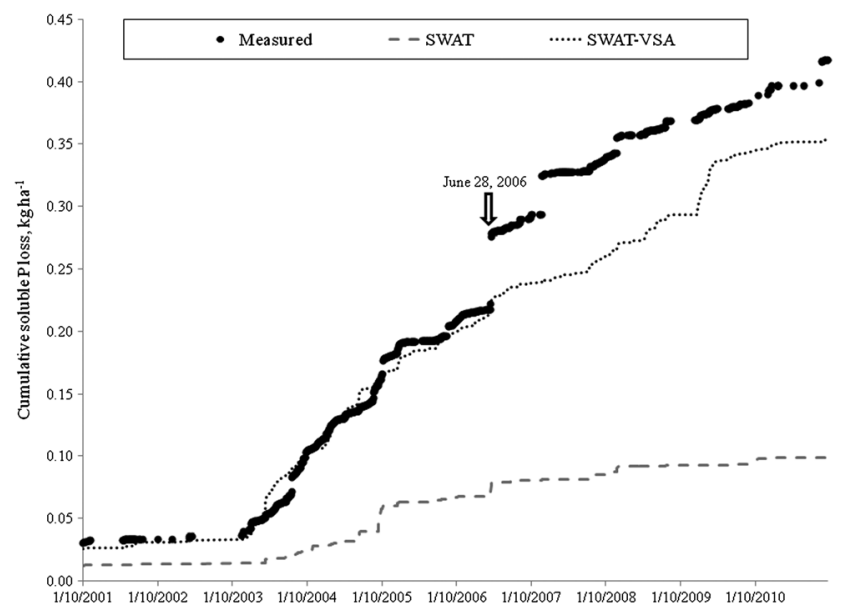

Figure 8. Cumulative P loss of measured orthophosphates, Soil and Water Assessment Tool (SWAT), and SWAT-variable source area (SWATVSA). Heavy flooding event in June 2008 indicated by arrow

the number of measured run-off events and the run-off volume. There was a relatively strong correlation between run-off frequency and $T I$ classes with more run-off events in high (saturated) $T I$ classes ( $>20$ events) and fewer events ( $<20$ events) on low (drier) TI soils (Figure 9). Fewer run-off events were estimated by SWAT for the different HRUs directly associated with the hillslope trenches, and there was very little variation predicted by SWAT (Figure 9).

The investigation into the modelled flow volume at the HRU level or even the field level as compared with measured flow volume at the soil trenches proved more daunting. Extracting modelled flow from the HRU and converting it to the appropriate units is quite possible, but the overland flow measured at the trenches did not correspond to the same area as the HRU or field. Therefore, we illustrate how the measured log flow at each trench classified by $T I$ class actually follows a similar trend as the

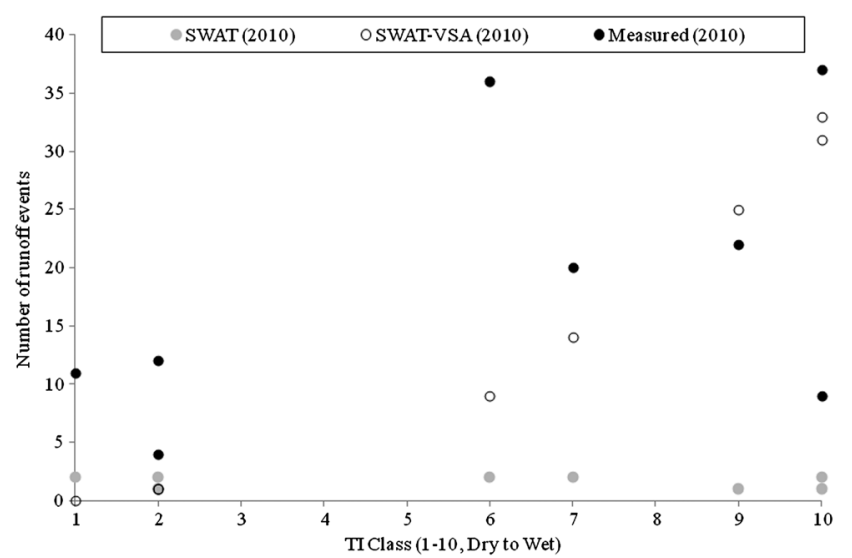

Figure 9. Number of run-off events at trench locations as shown in measured data and in the model modelled flow of the HRUs associated with each trench or flow increasing with $T I$ class (Figure 10). This same trend was not apparent with SWAT (grey circles; Figure 10), which varied little from trench to trench. Fields classified by high $T I$ values saturate quickly compared with the drier low $T I$ areas; thus, the majority of the watershed's run-off was produced in these saturated or VSAs.

Differences between SWAT and SWAT-VSA were most apparent when one examines the spatial distribution of soluble P loss (Figure 11a and b). In SWAT-VSA, soluble $\mathrm{P}$ loss was much more variable across the watershed and provided resolution at a sub-field level that was not apparent with SWAT. Soluble P loss across agricultural fields in the watershed averaged 0.21 (range: 0.0 to $>1.0 \mathrm{~kg} \mathrm{ha}^{-1}$ ) and 0.04 (range: 0.0 to $0.25 \mathrm{~kg} \mathrm{ha}^{-1}$ ) $\mathrm{kg} \mathrm{ha}^{-1}$ for SWAT-VSA and SWAT, respectively. Hay and small grain/hay (grass or alfalfa) fields had the highest soluble P losses in both SWAT and SWAT-VSA. The lowest soluble P losses (less than $0.01 \mathrm{~kg} \mathrm{ha}^{-1}$ ) were from forested areas, followed by grasslands/fallow areas and urban areas, such as roads, lanes and farm structures.

To corroborate the performance of SWAT and SWATVSA in predicting $\mathrm{P}$ in surface run-off from agricultural fields, we evaluated the relationship between predicted $\mathrm{P}$ losses and measured Mehlich-3 soil P across the Mattern subbasin at locations previously monitored by Buda et al. (2009b). They found that Mehlich-3 soil P served as a strong predictor of soluble $\mathrm{P}$ concentration in run-off and, when recent sources of soluble $\mathrm{P}$ were factored out (e.g. manure and fertilizer), followed a baseline, linear trend similar to that reported by Vadas et al. (2005) from a broader literature assessment that included rainfall simulation studies. Because SWAT predicts $\mathrm{P}$ loss $\left(\mathrm{kg} \mathrm{ha}^{-1}\right)$ rather than $\mathrm{P}$ concentration $\left(\mathrm{mg} \mathrm{l}^{-1}\right)$, predicted soluble P losses for HRUs in the Mattern subbasin were converted to $\mathrm{mg}^{-1}$ by factoring out predicted flows (1). SWAT-VSA produced a substantially stronger linear relationship between soluble $\mathrm{P}$ concentration and

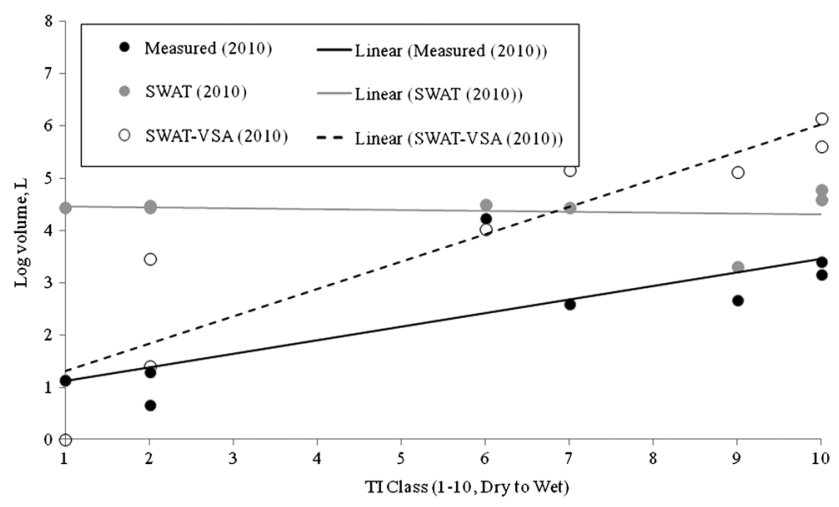

Figure 10. Comparison of the $\log$ of flow volume from the measured overland flow (in litres) and average flow depth from hydrologic response units; both flows were classified by topographic index (TI) class 


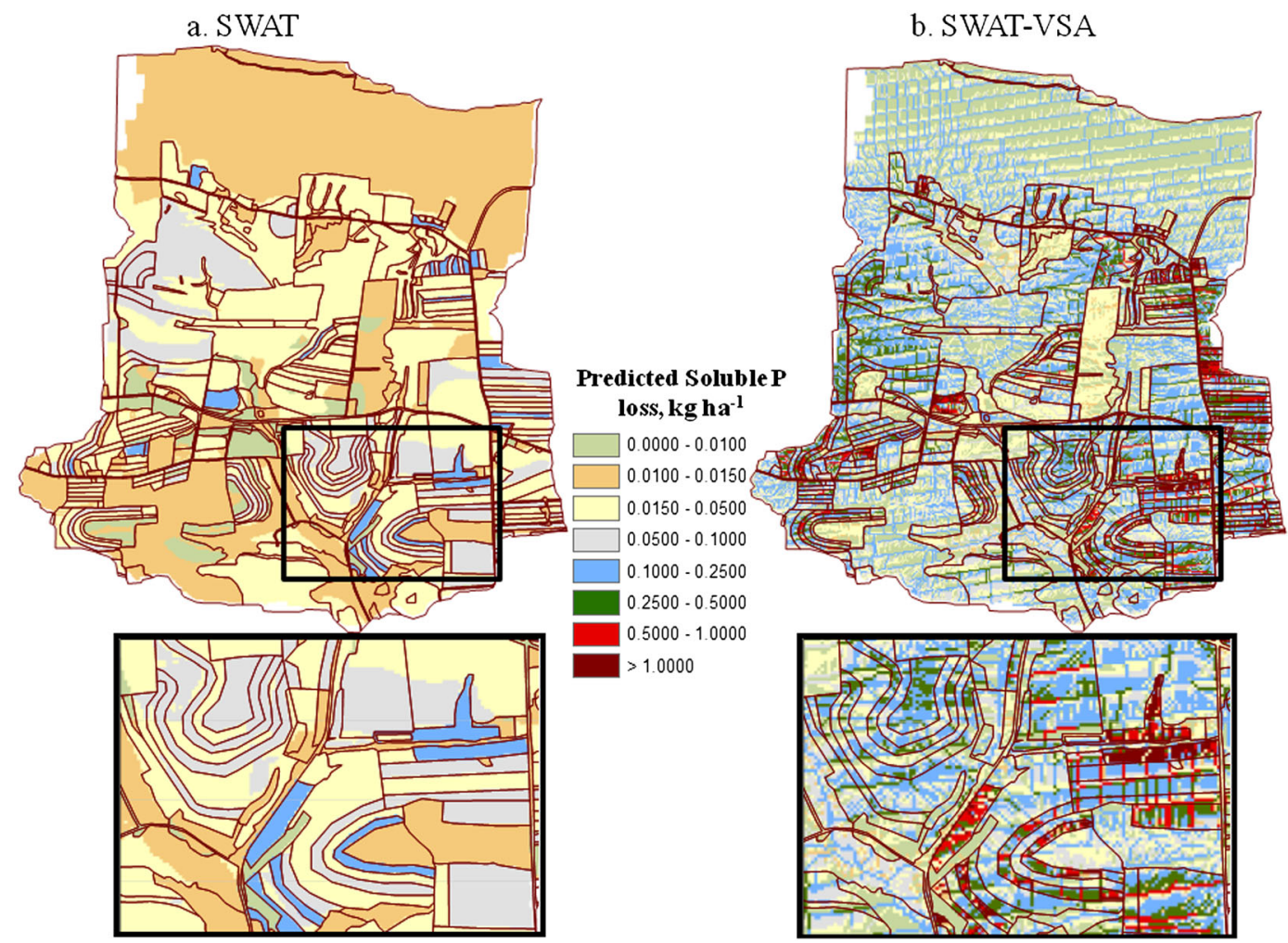

Figure 11. Spatial distribution of soluble P loss from agricultural fields as predicted by Soil and Water Assessment Tool (SWAT) (a) and by SWATvariable source area (SWAT-VSA) (b)

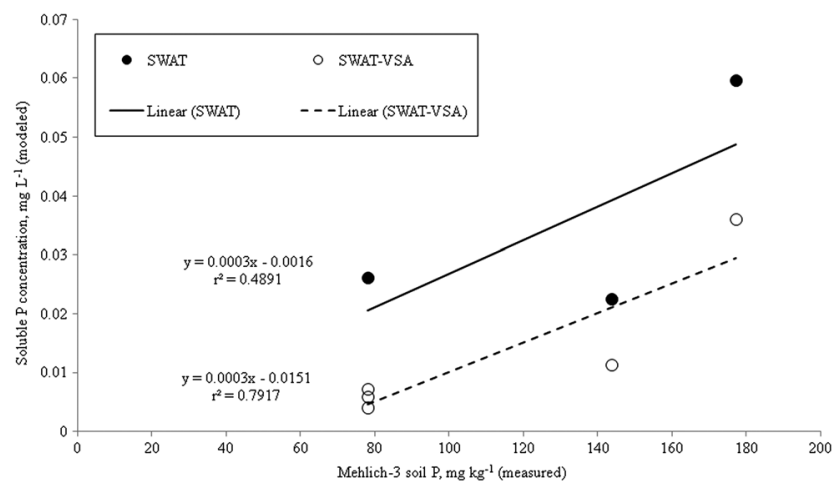

Figure 12. Relationship between predicted soluble P concentrations from Soil and Water Assessment Tool (SWAT) and SWAT-variable source area (SWAT-VSA) hydrologic response units and Mehlich-3 soil P measurements in close proximity to Buda et al. (2009b) run-off plots in the subbasin of Mattern

Mehlich-3 soil $\mathrm{P}\left(r^{2}=0.79\right)$ compared with SWAT $\left(r^{2}=0.49\right)$ suggesting an improved representation of field-scale controls on P run-off (Figure 12).

\section{IMPLICATIONS AND CONCLUSIONS}

Correctly and accurately modelling the hydrological and chemical variability governing $\mathrm{P}$ transport in a watershed with variable-depth soils and partial existence of fragipans requires extensive field knowledge and models capable of capturing a multitude of hydrological and biogeochemical processes. Our efforts comparing two versions of SWAT in the complex landscape of the WE38 test watershed provided good results for SWAT-VSA when comparing both the integrated (watershed outlet) and distributed (hillslope trenches) hydrology and adequate results when comparing $\mathrm{P}$ loss from the watershed. Both models performed similarly with respect to hydrology at the watershed outlet as indicated by their comparison statistics. However, SWAT-VSA improved representation of the timing, quantity and spatial distribution of surface run-off and as a result most likely better predicts soluble $\mathrm{P}$ loss and was consistent with previous studies in the watershed. This also suggests that the SWAT-VSA model is more physically realistic and thus should better predict soluble P loss.

These results indicate that SWAT-VSA was able to correctly identify and quantify critical source areas (e.g. those fields or areas likely to saturate and generate run-off and, if receiving high quantities or fertilizer, lead to excessive P loss) in watersheds dominated by VSA hydrology. This latest work with SWAT-VSA broadens its use into complex landscapes and continues the push towards integrating hydrologic modelling with $P$ management. 


\section{ACKNOWLEDGEMENTS}

The authors thank the staff of the USDA-ARS Pasture Systems and Watershed Management Research Unit for their contributions to the historical data used in testing the SWAT and SWAT-VSA models. In particular, Gordan Folmar provided the watershed monitoring data, Jim Richards (hydrologic technician) collected much of the land use data used in the study, and Brian Gray (temporary research assistant) oversaw vetting and transcription of key field management data.

\section{REFERENCES}

Archibald J. 2013. BaseflowSeparation function, package:EcoHydRology Ardia D, Mullen K. 2009. DEoptim: differential evolution optimization in R. R package version 2.2-2. Available from: http://CRAN.R-project. org/package=DEoptim (accessed October 2013).

Arnold JG, Allen PM, Volk M, Williams JR, Bosch DD. 2010. Assessment of different representations of spatial variability on SWAT model performance. Transactions of the ASABE 53(5): 1433-1443.

Beven K. 2001. Rainfall-Runoff Modeling: The Primer. John Wiley \& Sons, LTD.: Chichester, England; 360.

Beven KJ, Kirkby MJ. 1979. A physically-based, variable contributing area model of basin hydrology. Hydrological Sciences Bulletin 24 43-69. DOI: 10.1080/02626667909491834.

Beven K, Young P. 2013. A guide to good practice in modeling semantics for authors and referees. Water Resources Research 49: 5092-5098. DOI: 10.1002/wrcr.20393.

Bosch NS, Allan JD, Selegean JP, Scavia D. 2013. Scenario-testing of agricultural best management practices in Lake Erie watersheds. Journal Of Great Lakes Research 39(3): 429-436. DOI: 10.1016/j. jglr.2013.06.004.

Bryant RB, Veith TL, Feyereisen GW, Buda AR, Church CD, Folmar GJ, Schmidt JP, Dell CJ, Kleinman PJA. 2011. U.S. Department of Agriculture Agricultural Research Service Mahantango Creek Watershed, Pennsylvania, United States: Physiography and history. Water Resources Research 47: W08701. DOI: 10.1029/ 2010WR010056.

Buda AR, Kleinman PJA, Srinivasan MS, Bryant RB, Feyereisen GW. 2009a. Factors affecting surface runoff generation from an agricultural hillslope in central Pennsylvania. Hydrological Processes 23: 1295-1312. DOI: 10.1002/hyp.7237.

Buda AR, Kleinman PJA, Srinivasan MS, Bryant RB, Feyereisen GW. 2009b. Effects of hydrology and field management on phosphorus transport in surface runoff. Journal of Environmental Quality 38: 2273-2284. DOI: 10.2134 jeq2008.0501

Buda AR, Feyereisen GW, Veith TL, Folmar GJ, Bryant RB, Church CD, Schmidt JP, Dell CJ, Kleinman PJA. 2011a. U.S. Department of Agriculture Agricultural Research Service Mahantango Creek Watershed, Pennsylvania, United States: Long-term stream discharge database. Water Resources Research 47: W08703. DOI: 10.1029/ 2010WR010059.

Buda AR, Veith TL, Folmar GJ, Feyereisen GW, Bryant RB, Church CD, Schmidt JP, Dell CJ, Kleinman PJA. 2011b. U.S. Department of Agriculture Agricultural Research Service Mahantango Creek Watershed, Pennsylvania, United States: Long-term precipitation database. Water Resources Research 47: W08702. DOI: 10.1029/ 2010WR010058.

Buda AR, Kleinman PJA, Feyereisen GW, Miller DA, Knight PG, Drohan PJ, Bryant RB. 2013. Forecasting runoff from Pennsylvania landscapes. Journal of Soil and Water Conservation 68(3): 185-198. DOI: 10.2489/ jswc.68.3.185.

Church CD, Veith TL, Folmar GJ, Buda AR, Feyereisen GW, Bryant RB, Schmidt JP, Dell CJ, Kleinman PJA. 2011. U.S. Department of Agriculture Agricultural Research Service Mahantango Creek Watershed, Pennsylvania, United States: Long-term water quality database.
Water Resources Research 47: W08704. DOI: 10.1029/ 2010WR010060.

Crossman J, Futter MN, Oni SK, Whitehead PG, Jin L, Butterfield D, Baulch H, Dillon PJ. 2013. Impacts of climate change on hydrology and water quality: future proofing management strategies in the Lake Simcoe watershed, Canada. Journal of Great Lakes Research 39(1): 19-32. DOI: http://dx.org/10.1016/j.jglr.2012.11.003.

Dahlke HE, Easton ZM, Fuka DR, Lyon SW, Steenhuis TS. 2009. Modelling variable source area dynamics in a CEAP watershed. Ecohydrolology 2: 337-349. DOI: 10.1002/eco.58.

Duriancik LF, Bucks D, Dobrowolski JP, Drewes T, Eckles SD, Jolley L, Kellogg RL, Lund D, Makuch JR, O'Neill MP, Rewa CA, Walbridge MR, Parry R, Weltz MA. 2008. The first five years of the Conservation Effects Assessment Project. Journal of Soil and Water Conservation 63: 185A-197A. DOI: 10.2489/jswc.63.6.185A.

Easton ZM, Gérard-Marchant P, Walter MT, Petrovic AM, Steenhuis TS. 2007. Hydrologic assessment of an urban variable source watershed in the Northeast United States. Water Resources Research 43: W03413. DOI: $10.1029 / 2006$ WR005076.

Easton ZM, Fuka DR, Walter MT, Cowan DM, Schneiderman EM, Steenhuis TS. 2008. Re-Conceptualizing the Soil and Water Assessment Tool (SWAT) model to predict runoff from variable source areas. Journal of Hydrology 348: 279-291. DOI: 10.1016/j. jhydrol.2007.10.008.

Easton ZM, Walter MT, Zion M, Schneiderman EM, Steenhuis TS. 2009. Including source-specific phosphorus mobility in a nonpoint source pollution model for agricultural watersheds. Journal of Environmental Engineering, ASCE 135(1): 25-35. DOI: 10.1061/(ASCE)0733-9372 (2009)135:1(25).

FAO. 2007. Digital Soil Map of the World. Available from: http://www.fao. org/geonetwork/srv/en/metadata.show?id=14116 (accessed August 2013).

Fuka DR, Walter MT, MacAllister CA, Steenhuis TS, Easton ZM. 2013. SWATmodel: A multi-OS, multi-platform SWAT model package in R. Journal of the American Water Resource Association, in press.

Gassman PW, Reyes M, Green CH, Arnold JG. 2007. The Soil and Water Assessment Tool: Historical development, applications, and future directions. Transactions of the American Society of Agricultural and Biological Engineers (Invited Paper Series) 50(4): 1211-1250.

Gburek WJ, Drungil CC, Srinivasan MS, Needelman BA, Woodward DE. 2002. Variable-source-area controls on phosphorus transport: Bridging the gap between research and design. Journal of Soil and Water Conservation 57(6): 534-543.

Gburek WJ, Needelman BA, Srinivasan MS. 2006. Fragipan controls on runoff generation: Hydropedological implications at landscape and watershed scales. Geoderma 131: 330-344. DOI: 10.1016/j. geoderma.2005.03.021.

Ghebremichael LT, Veith TL, Watzin MC. 2010. Determination of critical source areas for phosphorus loss: Lake Champlain Basin, Vermont. Transactions of the American Society of Agricultural and Biological Engineers 53(5): 1595-1604.

Gitau MW, Veith TL. 2006. Quantifying the effects of phosphorus control Best Management Practices. Modeling Phosphorus in the Environment, Chapter 15: 351-382.

Hewlett JD, Hibbert AR. 1963. Moisture and energy conditions within a sloping soil mass during drainage. Journal of Geophysical Research 68(4): 1081-1087. DOI: 10.1029/JZ068i004p01081

Horton RE. 1933. The role of infiltration in the hydrological cycle. Transactions of the American Geophysical Union 14: 446-460.

Ihaka R, Gentleman R. 1996. R: A language for data analysis and graphics. Journal of Computational and Graphical Statistics 5(3): 299-314. DOI: 10.1080/10618600.1996.10474713.

Kleinman PJA, Sharpley AN, Buda AR, McDowell RW, Allen AL. 2011. Soil controls of phosphorus runoff: management barriers and opportunities. Canadian Journal of Soil Science 91: 329-338. DOI: 10.4141/cjss09106.

Lindeburg K. 2011. Silty Mantles and Fragipans in Pennsylvania Soils. MS thesis, Pennsylvania State University, University Park, PA.

Lyne VD, Hollick M. 1979. Stochastic time-variable rainfall-runoff modelling. Hydrology and Water Resources Symposium, Perth, Institution of Engineers, Australia.

Lyon SW, Walter MT, Gerard-Marchant P, Steenhuis TS. 2004. Using a topographic index to distribute variable source area runoff predicted 
with the SCS curve-number equation. Hydrological Processes 18: 2757-2771. DOI: 10.1002/hyp.1494.

Lyon S, Seibert J, Lembo AJ, Walter MT, Steenhuis TS. 2006. Geostatistical investigation into the temporal evolution of spatial structure in a shallow water table. Hydrology and Earth System Sciences Discussions 10: 113-125. DOI: 10.5194/hess-10-113-2006.

Nash JE, Sutcliffe JV. 1970. River flow forecasting through conceptual models part I: a discussion of principles. Journal of Hydrology 10: 282-290.

Nathan RJ, McMahon TA. 1990. Evaluation of automated techniques for base flow and recession analysis. Water Resources Research 26(7): $1465-1473$.

Needelman BA, Gburek WJ, Petersen GW, Sharpley AN, Kleinman PJA. 2004. Surface runoff along two agricultural hillslopes with contrasting soils. Soil Science Society of America Journal 68: 914-923. DOI: 10.2136/sssaj2004.9140.

Nietsch SL, Arnold JG, Kiniry JR, Williams JR, King KW. 2009. Soil and Water Assessment Tool, Theoretical Documentation, Version 2009, Technical Report TR-406. Texas Water Resources Institute: College Station, TX

Nietsch SL, Arnold JG, Kiniry JR, Williams JR. 2011. Soil and Water Assessment Tool Theoretical Documentation, Version 2009. Texas Water Resource Institute: College Station, TX.

Niraula R, Kalin L, Srivastava P, Anderson C. 2013. Identifying critical source areas of nonpoint source pollution with SWAT and GWLF. Ecological Modelling 268: 123-133. DOI: 10.1016/j. ecolmodel.2013.08.007.

Pradhanang S, Mukundan R, Schneiderman EM, Zion M, Anandhi A, Pierson DC, Frei A, Easton ZM, Fuka DR, Steenhuis TS. 2013. Streamflow responses to projected climate change in New York City water supply watershed. Journal of American Water Resource Association: 1-19. DOI: 10.1111/jawr.12086.

Qui Z, Walter MT, Hall C. 2007. Managing variable source pollution in agricultural watersheds. Journal of Soil and Water Conservation 63(3): 115-122. DOI: 10.1007/s00267-003-2910-0.

R Core Team. 2013. R: A Language and Environment for Statistical Computing. R Foundation for Statistical Computing: Vienna, Austria. ISBN 3-900051-07-0, Available from: http://www.R-project.org/.

Reckhow KH, Chapra SC. 1983. Confirmation of water quality models. Ecological Modelling 20: 113-133. DOI: 10.1016/0304-3800(83) 90002-9.

Saxton KE, Rawls WJ. 2006. Soil water characteristic estimates by texture and organic matter for hydrologic solutions. Soil Science Society of America Journal 70(5): 1569-1578. DOI: 10.2136/sssaj2005.0117

Schneiderman EM, Steenhuis TS, Thongs DJ, Easton ZM, Zion MS, Mendoza GF, Walter MT, Neal AL. 2007. Incorporating variable source area hydrology into the curve number based Generalized Watershed Loading Function model. Hydrological Processes 21(25): 3420-3430. DOI: 10.1002/hyp.6556.

Sharpley AN, Kleinman PJA, McDowell RW, Gitau M, Bryant RB. 2002. Modeling phosphorus transport in agricultural watersheds: Processes and possibilities. Journal of Soil and Water Conservation 57: 425-439.

Sharpley AN, Kleinman PJA, Flaten DN, Buda AR. 2011. Critical Source Area Management of Agricultural Phosphorus: Experiences, Challenges and Opportunities. Water Science Technology 64: 945-952. DOI: 10.2166/wst.2011.712.

Srinivasan MS, Gburek WJ, Hamlett JM. 2002. Dynamics of stormflow generation - A field study in east-central Pennsylvania, USA. Hydrological Processes 16(3): 649-665. DOI: 10.1002/hyp.311.

Steenhuis TS, Winchell M, Rossing J, Zollweg JA, Walter MF. 1995. SCS runoff equation revisited for variable-source runoff areas. Journal of Irrigation and Drainage Engineering 121: 234-238. DOI: 10.1061/ (ASCE)0733-9437(1995)121:3(234).

USDA-NRCS. 2008. Soil Survey Geographic (SSURGO) database for Northumberland County, Pennsylvania, Available from: http://www. nrcs.usda.gov/products/datasets/sssurgo/.

USDA-SCS (Soil Conservation Service). 1972. National Engineering Handbook, Part 630 Hydrology, Section 4, Chapter 10.

USEPA. 2002. National Water Quality Inventory. US EPA: Washington, DC.

USEPA. 2006. National Water Quality Inventory. US EPA: Washington, DC.

Vadas PA, Kleinman PJA, Sharpley AN. 2004. A simple method to predict dissolved phosphorus in runoff from surface applied manures. Journal of Environmental Quality 33: 749-756. DOI: 10.2134/ jeq2004.7490.

Vadas PA, Kleinman PJA, Sharpley AN, Turner BL. 2005. Relating soil phosphorus to dissolved phosphorus in runoff: A single extraction coefficient for water quality modeling. Journal of Environmental Quality 34: 572-580. DOI: 10.2134/jeq2005.0572.

Vadas PA, Good LW, Moore Jr PA, Widman N. 2009. Estimating Phosphorus Loss in Runoff from Manure and Fertilizer for a Phosphorus Loss Quantification Tool. Journal of Environmental Quality 38: 1645-1653. DOI: 10.2134/jeq2008.0337.

Van Liew MW, Veith TL, Bosch DD, Arnold JG. 2007. Suitability of SWAT for the Conservation Effects Assessment Project: Comparison on USDA Agricultural Research Service Watersheds. Journal of Hydrologic Engineering 12(2): 173-189. DOI: 10.1061/(ASCE) 1084-0699.

Van Liew MW, Feng S, Pathak TB. 2012. Climate change impacts on streamflow, water quality, and best management practices for the Shell and Logan Creek watersheds in Nebraska. International Journal of Agriculture and Biological Engineering 5(1): 13-34. DOI: 10.3965/j. ijabe.20120501.003.

Veith TL, Sharpley AN, Arnold JG. 2008. Modeling a Small, Northeastern Watershed with Detailed Field-Level Data. Transactions of the American Society of Agricultural and Biological Engineers 51(2): 471-483.

Weyman DR. 1973. Measurements of the downslope flow of water in a soil. Journal of Hydrology 20(3): 267-288. DOI: 10.1016/0022-1694 (73)90065-6.

White MJ, Storm DE, Smolen MD, Zhang H. 2009. Development of a quantitative pasture phosphorus management tool using the SWAT model. Journal of the American Water Resources Association 45(2): 397-406. DOI: 10.1111/j.1752-1688.2008.00295.x.

Woodbury J, Shoemaker CA, Cowan D, Easton ZM. 2013. A Comparison of SWAT models for the Cannonsville Watershed with and without Variable Source Area Hydrology. Journal of American Water Resource Association: 1-15. DOI: 10.1111/jawr.12116. 